\title{
A Typography Study of Negotiation and Identity at Dolly
}

\author{
Maria Nala Damajanti \\ Visual Communication Design \\ Petra Christian University Surabaya, Indonesia \\ mayadki@petra.ac.id
}

\author{
Elisabeth Christine Yuwono Visual Communication \\ Design \\ Petra Christian University Surabaya, Indonesia \\ xiney@petra.ac.id
}

\begin{abstract}
The Dolly area was widely known as a famous prostitution area in Surabaya, which was supposedly the largest in Southeast Asia. After going through a number of upheavals and rejection, finally this prostitution area was closed in 2014 by the government and returned as a residential area. Most societies supported the decision, but not a few rejected it. Until 2018 the upheaval is still going on. From the remaining signage, it is known that the prostitution took place amidst dense population. This research aims to investigate the typographical benefits and roles for the communities in this region. In-depth observations and interviews confirm the important role of typography for the citizens in this place. It functions as identities and is also a meaningful resistance model and even negotiation - an unresolved turmoil. Simple appearance of the signage reveals a model of citizen interaction when dealing with problems. The role of the signage is directly related to the issue of their identity and existence. The most important thing in this research is to record a visual culture practices as part of urban culture phenomenon in Surabaya.
\end{abstract}

Keywords: typography, identity, negotiation, resistance, Dolly, Surabaya, signage

\section{INTRODUCTION}

Among the various writings on signages that are left behind in Putat Jaya village, Sawahan District, in the city of Surabaya, especially in the area better known as the former 'Dolly' or 'Jarak-Dolly' prostitution area, which connects this region between the past and present is a signage that reads 'rumah tangga' (household), 'Members of $A B R I / T N I$ (the Indonesian army) are prohibited from entering' and 'parking'. The writings are attached to the house structure as a guide for visitors. Although there is no longer a lot of signages, it still clearly shows that there is a certain meaning for its inhabitants.

When the Jarak-Dolly area still functions as a prostitution area, the signage clearly differentiates between the dwelling that functions as normal household residences and those that are not. The house that functions as a 'wisma' or a guesthouse (the term for a prostitution house) is filled with decorative lights that is different from an ordinary house. A house that functions as a residence places a sign that reads 'household'. The house that functions as a place of prostitution or a guesthouse, in addition to writing the name of the guesthouse there is a sign that says 'Members of $A B R I / T N I$ are prohibited from entering'. The house that functions as a parking lot has the 'parking' sign. However, since the Surabaya city government closed the prostitution area, the signages have disappeared and are now rare. This research will focus on the signages that read 'household' because of their presence that sprawls throughout former prostitution houses in Jarak-Dolly that distinguish them from guesthouses. This particular signage is now still found among people's homes, though not as much as before. Signage samples are taken randomly until a number of variations have been collected. The term household has a special meaning for the people at Jarak-Dolly. According to the Kamus Besar Bahasa Indonesia, the word household means (1) relating to the affairs of home life, (2) relating to the family. What are the benefits and meanings of the word on the signage installed in nonwisma houses is something that will be explored further.
This paper is a typography study as a visual culture research. The study begins by highlighting typography on 'household' signages. Observations begin with attention to the visual signage displays. Font characters and their application in the compositions of the signages are identified before examining their meanings. Typography is the study of the ins and outs of letters, but cultural aspects are an integral part of the analysis, with a formal analysis of the form of signages and typefaces from the variables studied. Furthermore, how the application of typography on signages form meaning will be seen with the ethno-semiotics approach. Ethno-semiotics is a method that connects text reading with daily life [1]. 'Household' signage is seen as a text that cannot be separated from the social structure of the community. So this is a micro research that looks at the relation of a text to everyday life where socio-cultural backgrounds contribute to meaning. Through literature studies, observations and in-depth interviews, important values of signage and discourse that surrounds its representation are discovered. The interviewees consist of housewives who are ordinary citizens who have 'household' signages attached to their houses, the mother of a former procurer or madam (wisma owner), the $R T$ (neighborhood administrator), the Camat (sub-district officer), and a number of other residents from various professions who live in the prostitution area of Jarak-Dolly.

\section{SIGNAGE}

The role of typography in society has always been great. It is in the frontline as a medium of communication. Typography means the study of letters as stated by Danton Sihombing in his book Typography in Graphic Design [2]. So for a signage, the aspects that are considered are the level of legibility and visibility in addition to the aesthetics of the letters and the media used, including how its application play a role in conveying the message.

Not many homeowners maintain the 'household' signages. Most of the residents have disposed them after the closing. Most of the samples found are not intact and obscure. Some letters are missing. There are those that the 
writings look faded but still clearly legible. Examples of signs of 'household' are found scattered in the Putat Jaya and Kupang Gunung Timur areas. Some are handwritten, some are printed on paper or cardboard, some are wood carvings. The handwriting ones are not too neat. In writing, there is a combination of uppercase and lowercase or all uppercase letters, all of which consist of serif and san-serif types. They are written with a marker on a thick carton that is nailed or affixed to the front door of the house. Some are printed on paper with san-serif and serif letters and only black. The level of readability is generally quite good. From a reading distance of 2-3 meters it is still clearly legible. The stronger signboard type uses wood carving. From the sample found, this nameplate is colored like the color of the door. The letters used are scripts and italics. This nameplate position is quite visible because it is located at the front of the house. There is no sign of full color or strong decorative elements found. Signages are generally installed in the area around the door of the house, in the doorway or above the door. The writing 'household' consists of large sized letters, between $520 \mathrm{~cm}$ in height and $20-40 \mathrm{~cm}$ in length. The height of the signages also vary between 10 $30 \mathrm{~cm}$. Visually, the font size and clarity of writing appear to be what is most important. Then typographically, the writing on the signboard is quite legible, visible, and readable even though in general the signage looks simple. Thus it can be concluded that in this case the application of typography on the 'household' signage prioritizes aspects of information clarity more than aesthetics.

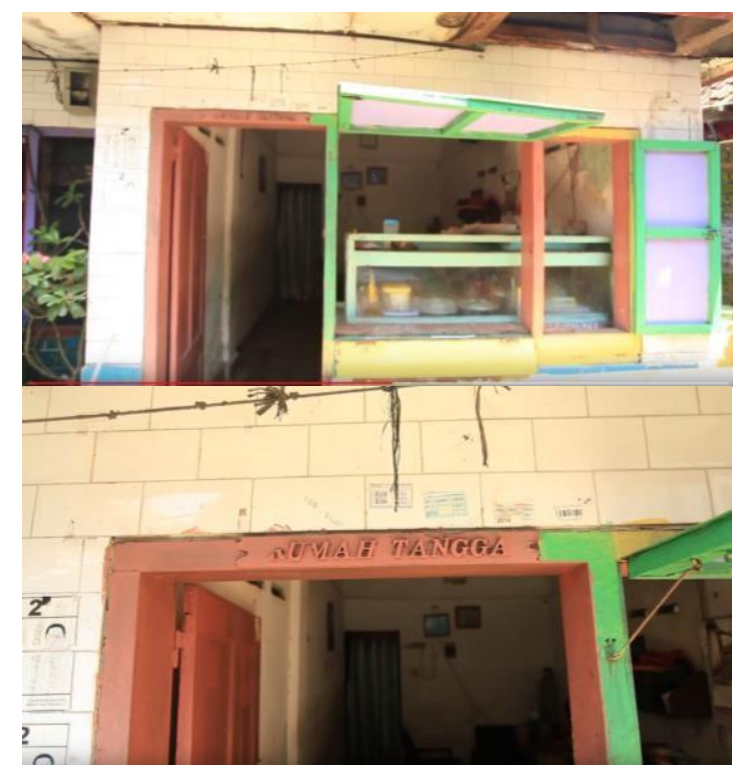

Figure.1. 'Rumah Tangga' (Household) Signage

\section{IDENTITY, RESISTANCE, AND NEGOTIATION}

Since when the tradition of installing the signage above is not known exactly. However, Purnomo and Siregar have noted that in the old prostitution area in Bangunrejo, Surabaya, there are also 'household' writings on the doors of houses that are not places of prostitution [4]. Residential conditions that blend with the prostitution area encourage families or residents who live around the guesthouses to use these conditions by doing business selling, starting from food stalls, coffee shops, offering daily necessities, ironing services, renting out boarding rooms, selling prepaid credits, opening grocery stalls, providing room sticker and other installing services. Business is carried out primarily to serve the sex workers and also guests visiting the area. Renting out a parking lot is one of the businesses that has mushroomed throughout the Jarak-Dolly area. All of these businesses are carried out by residents in their homes along with taking care of their families. The financial results obtained are said to be plentiful and very easy through these efforts. However, having a household around the location is not easy.

According to a number of residents, they are really ashamed to claim to live in the area. This feeling is not only felt by children. Parents feel the same way. Some people do not want to acknowledge where they live to their families back in the village. However, they do not have the ability to move to another place. Some interviewees feel that it is not safe to raise children there. When in school their children are often ridiculed for living in this location. Even if they get off a public vehicle they choose to go down in a place far from home because they don't want to be considered part of the prostitution complex. It should be noted that houses that do not install the 'household' signage and do not have a guesthouse name may be places that also rent out sexual transactions as said by a former madam and 'wisma' owner. Family homes with many 'household' signages open food stalls that usually serve prostitutes or anyone. Such is the story of a mother who lived more than 20 years in Putat Jaya, RW 11 / RW 3. Her parents used to rent out boarding rooms, offering ironing and washing services, as well as opening food stalls. Thus, this family also has 'household' signages in their homes. The source of livelihood of most families there is obtained from serving the sex workers, their guests, or anyone visiting there. However, even though they have installed the 'household' signage sometimes there are also guests who enter their homes looking for sex workers, such are the statements of some residents.

It can be concluded that the signage functions as identification. The first function is to mark and inform visitors that this is a normal household that is different from other houses around it. In other words, this house is not a guesthouse or a wisma. The second function is to drive away visitors who want to find sex workers. This was said by a number of interviewees because they are often visited by visitors who are looking for sex workers. This usually happens if the visitor doesn't immediately find the signage with the word 'household' or due to something else they do not know. Therefore, it can be concluded that the signage is intended to clarify the status of the house and clarify the family status of the residents. In addition, it also serves to explain that the house is not a guesthouse or associated with wisma activities, and does not do sexual transactions.

From the explanation above, there are also other efforts to declare the profession of the house occupants that are different from other houses in the vicinity that do not install the signage. It also appears that the signage is an identity that is intended for residents who are expected to provide a sense of security in driving away unwanted strangers or visitors and to defend their image against the views of the general public. One thing that needs to be observed is that, visibly, ordinary houses and guesthouses look the same when seen during the day. This prostitution complex only operates from evening to night so that the wismas are easily recognizable by the flickering of the 
lights. Then it can be said that the 'household' signage is only evident during the day, so that the signage certainly has another meaning, not just ordinary identity signage.

\section{DISCUSSION}

From the explanation above it is known that the 'household' signage clearly has meaning for anyone who comes to the Jarak-Dolly complex, and especially for those who live in this area, up until before the prostitution activities are banned here. From interviews, those who installed the 'household' signage have a strong feeling of pride that they (as family) are not involved in prostitution as procurers (wisma owners) or as providers of sex workers. They are grateful for not participating in sex work or offering those services, even though they live in the area of a prostitution complex. Both are, however, important professions in the practice of prostitution. Nevertheless, in reality the families admit to have taken advantage of it. The family's economy is guaranteed as long as the practice of prostitution is not prohibited. Therefore, for local residents the signage is an important symbol of family.

On the other hand, the role of the signage can also be viewed from a different angle, namely when it is now prohibited from prostitution and the signage is still left installed. It then exists among the majority of residents' homes who no longer put up guesthouses. As in gestalt, this condition actually brings a message of new identity to the owner. They are stating that their houses are ordinary people's homes that are considered 'good' or 'positive' or 'normal' in the general norms of society. This condition has been going on for a long time, where they are not involved or are part of the practice of prostitution, which is the view or identity that they have avoided so long ago. At the same time, they are stating that those that do not install the 'household' signage may be the opposite party, namely a negative party or a bad party that does not meet the standards of community norms. It could be, this is a form of indirect statement that is not or has not been realized.

With the ethno-semiotics approach, the 'household' signage omission makes it a text that can be read differently. Its existence clarifies the position of two opposing camps. It reveals binary positions that separate professions that are considered negative, namely those related to prostitution in the eyes of the public, from any other profession which is not considered negative. It can also be seen as a sign that sorts people or family that is considered good from the bad. At least one party states they are better than the other. It is a discourse of professional differences that becomes a benchmark for the identity of a person or group of people. This is where the identity is deemed necessary, even very important to be stated or proclaimed to the wider community.

Identity is the result of a learning process. Apart from the above interpretation, the 'household' signage is proof of identity that is emphasized so that it appears as an attempt to defend itself by something that is not expected, especially when they cannot escape from unwanted situations. It is a form of resistance which according to Foucault will always be there, where there is a power relation, which is closely related to their existence [5] [6]. It is not a hierarchical structural relationship but a result of certain relationships that are unavoidable due to housing in the prostitution area. This condition can also be understood that there are many visitors who go back and forth looking for sex workers in the area where they live. In this relationship, negotiations appear to be one form of JarakDolly community's resistance as happens in the relationship between producers and consumers, food stall owners and buyers, boarding madam with sex worker tenant, providers of ironing services with sex worker customers, and others. In this case, an identity that is originally seen as a form of resistance actually in practice developed into negotiation. Wenger (1999) as quoted by Atkinson, claims that identity allows one to learn from one experience to another, and that identity is developed through negotiation of social meaning [7]. Interactions that occur in the JarakDolly community are between refusing, accepting and cooperating. Refusing to be equated, but in conditions where there is no choice, there is such acceptance that a kind of cooperation is formed. The desired separation eventually seems thin because in practice there is a strong relationship, almost overlapping between the two parties because there is dependence, mutual need and mutual benefit. With this background, it is understandable why the withdrawal of the closure of prostitution in Jarak-Dolly takes a long time where for the people there the matter of closure and prohibition of prostitution is considered impossible. Now, the 'household' signage has been included in a different new discourse.

\section{CONCLUSION}

The approach in the interpretation above is based on the desire to explore and have a record of visual culture practices in a group of urban people who have different sides. An urban culture phenomenon that should be recorded as part of Surabaya history. Its usefulness is certainly related to the idea of how social struggle creates resistance in the efforts of group survival. The method used is fluid, namely negotiating. Identity is fluid, depending on which angle you want to see. It can be said that this is the initial research on the issue of identity where typography is a sign of the beginning of a turbulence.

Signage with the word 'household' for residents who live in the former prostitution area of Dolly is found to have an important meaning. Although the simple appearance of the signage reveals a model of citizen interaction when dealing with problems around it, the role of the signage is directly related to the issue of their identity and existence. Furthermore, by allowing the signage to remain installed on the doors of the houses, it is suspected that the discourse is not over. In line with Hall, the analysis and findings above are not one final truth. This interpretation is open and productive to be reinterpreted in an endless circle of meanings [8].

\section{REFERENCES}

[1] Yasraf Amir Piliang, "Hypersemiotics. Cultural studies commentation for the death of meaning" (Hipersemiotika. Tafsir cultural studies atas matinya makna), Jalasutra, 2003, pp. 276-277.

[2] Danton Sihombing, "Typography in graphic design"(Tipografi dalam desain grafis). Gramedia, 2015.

[3] Tjahjo Purnomo and Ashadi Siregar, "Dolly. Dissecting the world of prostitution in Surabaya, cases of dolly prostitution complex" (Dolly. Membedah dunia pelacuran Surabaya, kasus kompleks pelacuran Dolly), Grafiti Pers, April 1983, p. 24. ibid pp. 6-9.

[4] John Storey. "Cultural Theory and Popular Culture. A Reader." Harlow: Prentice Hall, 1998, p.167. [8]

[5] Abdil Mughis Mudhoffir, Teori Kekuasaan Michel Foucault: Tantangan bagi Sosiologi Politik, Jurnal Sosiologi MASYAR AK 
AT Vol. 18, No. 1, Januari 2013: 75-100 [Online] Available: http://journal.ui.ac.id/index.php/mjs/article/view/3734/2973

[6] E. Wenger, Communities of practice: learning, meaning, and identity (1st ed). Cambridge: University Press, 1999. https://woknowing.wordpress.com/2010/10/14/social-negotiationasa-central-principle-of-constructivism/

[7] Stuart Hall, Jessica Evans and Sean Nixon, "Representation, second editon.” 2013., Singapore: Sage, 2013, p.27. 